\title{
Sociological Analysis of the Individual Motivations and of Social Origin of the Orientation of the Students of the State Universities of Yaoundé
}

\author{
MASSOMA Luc Stéphane* \\ Senior lecturer in the Department of Sociology, Anthropology and Social sciences for development University of \\ Maroua (Cameroon)
}

*Corresponding Author: MASSOMA Luc Stéphane, Senior lecturer in the Department of Sociology, Anthropologv and Social sciences for development Universitv of Maroua (Cameroon)

\section{SUMMARY}

The dynamics of guidance in school and professional settings remain of crucial interest in the lives of individuals, especially young people in school. These can be themselves actors of their orientation as they can be acted by external circumstances which do not depend on them and force them to choices which they undergo or which they accept willingly or reluctantly. Among these determinants external to the individual, we find the various social motivations which exert a coercion on the young people confronted with the decision to opt for a precise academic corridor, and, later, for a precise professional corridor. This article therefore explores without pretension to be exhaustive, some of these motivations that emerged from the responses of young people and students surveyed in Yaoundé, precisely in the university areas of Ngoa Ekelle and Soa. After initially highlighting certain motivations intrinsic to the individual, we focused here on elements and circumstances which produce an extrinsic coercion from which the young person often does not manage to escape in order to make his choice.

Observation of the performance of students at state universities in the city of Yaounde in recent decades reveals the existence of a problem. Students who had previously had a brilliant career in secondary schools face repeated failures. Blaming their intelligence quotients would be inappropriate because we could not then explain their previous successes. Several factors can justify student failures, among others: the lack of financial means which makes documentation difficult and causes many other damages, an unfavorable family context, or even previous successes due to practices such as fraud. Thus, the factors of failure at university are of various kinds. However, the many transfers from one university course to another, and even often from one university establishment to another lead one to think that student failures are often linked to problems of educational orientation. The motivations that push students to choose an academic career over another, starting from high school benches already, seem sufficiently diverse to give rise to a consistent study.

\subsection{Description of Empirical Activities}

Taking into account the comments of Mendras $(1989,1996)$ according to which "the definition of the situation, (...) is precious for sociological analysis", it is important to place limits that this article will not exceed. Several psychological or sociological studies have already been carried out on the academic failures of students at the universities of Yaoundé UY I and UY II). Thus, examining student failures is not one of the objectives of this reflection. There is also no question of doing a policy board study, although it is inevitable to mention it often. In our context, it is important to differentiate between guidance counseling and educational guidance seen from a more global perspective that includes vocational advice, but also many other determinants. This examination of the social motivations of the academic and professional choices of pupils and students is part of this overall academic orientation. The work here will consist of an examination of the determinants in terms of social motivations which enter into account in the decisions of young people confronted with the choice of an academic career.

The results presented in this article are based on data collected in one of our previous research. In said research, the data collection techniques employed were as follows: 
The interview or interview: we had to talk to students and various social actors who were able to influence their decisions regarding the choice of an academic path, such as parents or guidance counselors. These were open or semi-structured interviews as needed.

$>$ The focus group discussion: we formed a group of eight students for a discussion on what counts in the academic choices of the students.

The questionnaire survey:We aim to constitute a sufficiently representative sample of all the students of the state universities of Yaoundé, surveyed among 300 students of the universities of Yaoundé I and II. We went to meet them in mini-cities of Ngoa-Ekelle and Soa chosen arbitrarily. Out of the 300 questionnaires distributed, we came back in possession of 244 of which 235 (166 completed by students from the UYI (University of Yaoundé I) and 69 by those from the UYII (University of Yaoundé II) were used for the data processing, the other 9 not having been completed by students from the universities concerned by the survey. The questionnaire prepared for this survey was composed of open questions which left the respondent to formulate his answer,

TABLE1. Number of Faculties represented in our sample.

\begin{tabular}{|c|c|c|c|c|}
\hline FAS & FALSS & FSJP & FSEG & TOTAL \\
\hline 90 & 76 & 46 & 23 & 235 \\
\hline
\end{tabular}

Source : Our field survey.

We would like to point out that we have assimilated the students enrolled in the exact sciences of the grandes écoles to those of the Faculty of Sciences (FAS). This is the case, for example, for medical students, polytechnic students or those who study these sciences at the Ecole Normale Supérieure. Likewise, students of literature or humanities at the grandes écoles have been assimilated to students of the Faculty of Arts, Letters and Social Sciences (FALSS). This did not appear to have stood in the way of the proper conduct of the investigation. However, as much as necessary, we will take into account the particularities of these students.

Several students blame the university system, and even government education policy, for the failure rate in Yaoundé I and II universities, but as Lourie (1993) writes, "the responsibility ... cannot lie with the Ministry of education alone but must be shared" [Our translation]. Poor orientation has a large part of the responsibility for student performance. Lourie extends this responsibility to the unemployment problem. He writes: "graduate unemployment is linked to poor orientation of students" [Our translation]. The extent of the consequences of an academic misguidance shows how important the orientation is to a student's academic future. We have already established that some of the reasons for choosing a branch of study come from the influence on the academic orientation of the representations that a society has of it. It is now a question of taking a look at the resulting choices by listing these social motivations. Only the motivations mentioned by the students surveyed or interviewed will be taken into account. This directory cannot therefore claim to be exhaustive. It will be followed by a look at the circumstantial choices.

\section{MOTIVATIONS FOR VOLUNTARY GUIDANCE}

By voluntary orientation we mean here that in which the student has the last word and can make his choice while not being subjected to constraints from which he cannot escape. Under these conditions, he can deliberate, select, make a sovereign choice, in complete freedom. Obviously, in such circumstances the student assumes any error in his choice, although as Bourdieu (1997) asserts: "the 'choices of the 'free' and 'disinterested' subject that tradition extols are never totally independent of the mechanics of the field, therefore of the history of which it is the culmination " [Our translation] . Various social motivations drive students' voluntary choices.

\subsection{Choice Out of Love or Passion for the Industry}

It is true that passion can have a philosophical or psychological dimension, but we will look at it here as a product of social interaction as an element that can lead to the choice of a particular social status. Lage (1993) describes, for example, the case of a young person whom she interviewed: "François' father is a physicist. They both share a passion for crystals." [Our translation]. We see here that the passion for a discipline can be shared and even transmitted from one individual to another through social relations. 
Student passions do not come from nowhere. For example, it is no coincidence that almost all of the students with a baccalaureate $\mathrm{C}$ in our sample say that they are mainly passionate about three fields: computer science, mathematics and physics. Everything happens as if, when you have this baccalaureate, you are "socially programmed" for these sectors. A mathematics student expressed to us his astonishment and that of his comrades at the choice of one of their comrades who opted for economics: “... we were asking ourselves: what piqued him? How did it start? ...".

What students from the three fields mentioned above call passion for the field seems in fact to be a kind of 'social constraint' that they have accepted, integrated and learned to appreciate. The few holders of a baccalaureate $\mathrm{D}$ who are in these fields are, for the most part, really driven by passion. It is for this reason that they fought to be admitted in these courses which are opened to them in principle only in case of remarkable performances in mathematics and physics at the baccalaureate. But we find students with a baccalaureate D mostly in the other fields of the faculty of science. Several of them say they have always been fascinated by their sectors. But by investigating more deeply, we realize that in first intention, a considerable number of them wanted to study medicine, could not, and fell back on these courses. In fact, there is a lot of inconsistency in what students see as passion. The choices of sector by passion seem to be less numerous than what the following table shows:

TABLE2. Students who made choices out of passion

\begin{tabular}{|l|l|l|l|l|l|}
\hline & FAS & FALSS & FSJP & FSEG & TOTAL \\
\hline Effective & 46 & 36 & 21 & 4 & 107 \\
\hline Percent (\%) & 51.11 & 47.37 & 45.65 & 17.40 & 45.50 \\
\hline
\end{tabular}

Source: Our field survey

These data are approximate because the inconsistency between the responses of several students in our sample shows that many were not driven by the passion for the field of their choice as they claim. But there are still some who chose their pathways because of the irresistible attraction it exerted on them. For series A students, scientific streams being banned automatically, they can, during their three years in secondary school, indulge in dreaming of streams that fit into their field that they know. Law studies seem to be the ones that delight the greatest number of their votes, which justifies the overcrowding of the FSJP (our Faculty of Law and Politics) and the numerous consequent failures. These studies being more mediatized than the others, one can understand that they fascinate many. The fact that $45.64 \%$ of law students have chosen their course out of passion seems fairly close to reality. The majority of people who choose to enroll in economics do not do so out of love for these sciences because $17.40 \%$ say they are passionate about this field. Some language students would be fascinated by languages and their countries of origin (German, Spanish, ...). Psychology also fascinates several students who see in it a significant substitute for medicine that their orientation in literary series does not allow them to study.

There are therefore many students who choose their course out of passion, but the vast majority choose for other reasons. When we know that passion often leads to an investment that exceeds the requirements of the sector, we understand that more students who are passionate about what they do and have the skills to do it would lead to a drop in the failure rate. and orientation errors.

\subsection{Choice by Ambition}

A large number of students surveyed say they have chosen their courses because of their ambitions, which are twofold: purely academic ambitions and professional ambitions.

TABLE3. Students who have made choices by ambition

\begin{tabular}{|l|l|l|l|l|l|}
\hline & FAS & FALSS & FSJP & FSEG & TOTAL \\
\hline Effective & 50 & 34 & 30 & 12 & 126 \\
\hline Percent (\%) & 55.55 & 44.74 & 65.17 & 52.17 & 53.62 \\
\hline
\end{tabular}

Source: Our field survey

a) Choice by purely academic ambition

Dubet (1997) who will inspire Troger in the same direction, writes that there are "three factors of motivation of the students: the existence or not of a coherent professional project, the degree of 
integration into university life and the intellectual interest in studies. ". The choice by purely academic ambition refers here to the choices made without a thoughtful professional project. Some students enter university studies with the sole ambition of obtaining diplomas in a given discipline. They do not bother to educate themselves clearly on the professional outcomes of these studies. It is this mentality that Pacteau (1994) sums up as follows: "I am good at math, so I am going to do a scientific section", even without knowing where it leads.

The fact that the percentage of students who choose a course out of ambition amounts to $53.62 \%$ already implies that nearly half of the students arrive in faculty without ambition (46.38\%). But in addition, many of the ambitious students have ambitions limited to academic performance. The very high rate of law students at UY II who have professional ambitions is due to the fact that these studies are sufficiently well known that, while still in high school, the student has a more or less precise idea of their prospects. . Thus, it is difficult for someone to get involved in FSJP without having a certain profession in perspective, like a medical student who obviously knows what his studies are destined for. For economics students on the other hand, it is difficult to have anything other than an academic ambition at first. Outside of education, they have no standard openings, although those among them who manage to reach at least master's level are in high demand on the labor market. The lowest percentage of students who have chosen their courses out of ambition goes to the Faculty of Arts, Letters and Social Sciences (FALSS). This because, apart from teaching for those who go the furthest, these courses do not offer much certainty. Thus, out of the $44.74 \%$ of ambitious FALSS students, most have only an academic ambition. What may seem surprising is that the $55.55 \%$ of students of the Faculty of Science who were led in their choices by ambition are in the same situation. In general, those of them who manage to cross the course of the license realize that they are moving (if all goes well) towards a teaching career, the other openings not being numerous in the Cameroon and arising from the opportunism of the student. However, the majority of them are attracted by different professional perspectives.

b) Choice by professional ambition

In this case, the new student faced with the choice is armed with a "coherent professional project". He has a more or less clear idea of the socio-professional future linked to the sector to choose. He has already thought about his post-university social integration, and inquired of several seniors and / or educators. He comes out with fairly specific ambitions that he is generally determined to achieve. Interviews with a guidance counselor and students led us to the conclusion that students who have shown such curiosity are not legion in the two state universities of Yaoundé.

As we have already mentioned above, law students who have chosen by ambition necessarily have a professional ambition, given the nature of their course and the obvious opportunities. The courses of the other three faculties have:

$>$ few outlets;

$>$ or little-known opportunities (consultation for private or public organizations in the human sciences, for example);

$>$ or opportunities that involve a trip abroad, which is within the reach of very few people.

Thus, with a few rare exceptions, the students of these faculties who have a definite ambition are those who love teaching, or at least who are ready to teach, even without interest in the matter. Those who do not have education as their goal at the time of choice can hardly choose for professional ambition. This is also why there are so many students who do not know exactly where they are going. It is also for this reason that many students, after having trampled for years, drop out of studies. Those who become aware of their situation in time are reorienting themselves, in a much more realistic way this time. However, there are ambitions that the majority of students have, although they often don't know how to achieve them. Several students surveyed told us that they were led in their choice by the desire to be rich, to occupy good positions in society. But many think that it is by a lot of luck that we get there. They can therefore choose any course, provided that luck accompanies them. But these are more natural aspirations for well-being than professional ambitions.

\subsection{Choice of Prestige}

Some of the students surveyed designated the reputation of their courses as the driving force behind their choices: 
Sociological Analysis of the Individual Motivations and of Social Origin of the Orientation of the Students of the State Universities of Yaoundé

TABLE4. Students who have made prestigious choices

\begin{tabular}{|l|l|l|l|l|l|}
\hline & FAS & FALSS & FSJP & FSEG & TOTAL \\
\hline Effective & 20 & 8 & 5 & 5 & 38 \\
\hline Percent (\%) & 22.22 & 10.52 & 10.87 & 21.74 & 16.17 \\
\hline
\end{tabular}

Source: Our field survey

Guidance specialists seem to agree on the fact that many students choose prestigious courses without sometimes taking their aptitudes into account, which leads to failures. The scientific fields being the most prestigious, it is logical that the greatest percentage of students directed in their choices by the prestige is in the faculty of sciences. We have already shown that students with a baccalaureate $\mathrm{C}$ are often reluctant to go to courses that they consider below the " level of prestige " of the three " best courses " that their diploma allows them to choose. However, our sample shows us that there are at least as many students holders of a baccalaureate $\mathrm{C}$ as students holders of a baccalaureate $\mathrm{D}$ in the Faculty of Science. As a result, the prestige choice rate in this faculty could be higher than the 22.22 $\%$ that we obtained, since we can add to these students with a baccalaureate $\mathrm{C}$, several students with a baccalaureate $\mathrm{D}$ who chose physics, chemistry or biochemistry also by prestige. And even, less often, who choose computer science or mathematics if their baccalaureate transcripts and report cards allow it.

Due to the fact that from high school already, Series A is not the most prestigious, it is not surprising to find that prestigious choices are rarer in other faculties within the reach of literary baccalaureate holders. However, some courses often arouse this kind of motivation in the choices of students (psychology, law or political science). But the choices of prestige are mainly made by students of the Faculty of science. Beside them, there are motivations due to the circumstances.

\section{Circumstantial Motivations for University Orientation}

The circumstantial motivations here are those which do not depend on the student, but on the circumstances of his choice. Many students arrive at university without knowing exactly which course they want. Driven by circumstances of various kinds, they find themselves in one sector or another without having given it much thought. Others come with the intention of enrolling in specific studies, but find themselves doing something other than what they had planned.

\subsection{Inadequate Skills}

The mismatch between the aptitudes of some students and the requirements of the fields of study they choose seems to be one of the main causes of failure in UY I and II. It is therefore understandable that the education system is designed in such a way as to orient everyone towards the discipline or type of discipline which corresponds to their capacities.

Several of the students in our sample admit that they are not sure that their aptitudes are appropriate for their fields (33.19\%). Others simply recognize their incapacity.

TABLE5. Aptitudes of students for their courses

\begin{tabular}{|l|l|l|l|l|l|l|}
\hline & FAS & FALSS & FSJP & FSEG & TOTAL & Percent (\%) \\
\hline Yes & 45 & 53 & 26 & 14 & 138 & 58.72 \\
\hline No & 5 & 4 & - & 2 & 11 & 4.68 \\
\hline Perhaps & 33 & 19 & 19 & 7 & 78 & 33.19 \\
\hline NR & 7 & - & 1 & - & 8 & 3.41 \\
\hline
\end{tabular}

Source : Our field survey.

A large number of students have dreams and ambitions that their abilities cannot allow them to achieve. For example, several mediocre students in science subjects have nurtured the dream of being a medical doctor before being oriented to series A. They cannot study medicine, nor even study biochemistry or biology. They are constrained by their skills to enroll in branches of letters or humanities. Thus, the incapacity for what excites them motivates many in the alternative choice they make. They therefore choose taking in account their aptitudes as a criterion of choice. Sometimes the university institution makes the choice for these students.

\subsection{Forced Guidance}

It happens that a student enrolls in a specific field and ends up in another to his dismay. This is the case for some students in our sample : 
Sociological Analysis of the Individual Motivations and of Social Origin of the Orientation of the Students of the State Universities of Yaoundé

TABLE6. Students who have undergone a compulsory orientation

\begin{tabular}{|l|l|l|l|l|}
\hline FAS & FALSS & FSJP & FSEG & TOTAL \\
\hline 5 & 5 & - & - & 10 \\
\hline
\end{tabular}

Source: Our field investigation.

As it is obvious above, the problem of the imposed orientation arises essentially in the two faculties of the UYI. One can understand that it does not arise in the other two faculties (Faculty of Law and Political Sciences, and Faculty of Economic Sciences and Management), since they do not offer the new student a multitude of choices. In the Faculty of Science as in FALSS, when a student preenrolls, he must choose three streams ranked in order of importance. The purpose of these choices is to be able to resort to the other two choices in case the first is inappropriate. But in several cases, students are sent to courses that were not included in their three choices. These decisions of the institution are sometimes justified, since they are based on previous performances which do not correspond to the fields requested. But sometimes they are also more an administrative error than something else. According to our investigations, the students victims of this type of orientation represent $6.02 \%$ of the students, which is not negligible (out of 25,000 students, we would have 1506 having undergone a forced orientation). This phenomenon seems to be slightly more important in FALSS than in FAS.

\subsection{Financial Situation}

Fournier (1995), taking up the thought of Boudon, writes: "the choice of parents for the studies of their children results from the representations they have of the costs and advantages of long studies" [Our translation]. Several students surveyed rejected the responsibility of their difficulties on their socio-economic situations.

TABLE7. Students in financial difficulty

\begin{tabular}{|l|l|l|l|l|l|}
\hline & FAS & FALSS & FSJP & FSEG & TOTAL \\
\hline Effective & 19 & 23 & 6 & 2 & 50 \\
\hline Percent (\%) & 21.11 & 30.26 & 13.04 & 8.70 & 21.27 \\
\hline
\end{tabular}

Source : Our field survey.

It can be seen from this table that financial difficulties are major concerns for many students. From our interviews with the students of the various faculties and the questionnaire survey, it emerges that this problem is generalized to all these faculties. Under these conditions, it is normal for new students to classify their financial situation in their selection criteria. It is obvious that a student from a well-off background can, as long as he has the capacity, engage in difficult, long and expensive studies. The financial means at his disposal will provide him with all the necessary teaching material and protect him from financial worries. The same does not apply to students from disadvantaged backgrounds. Unless he is prepared to pay an additional price (by engaging in extra-curricular income-generating activities, for example, if he can find one), he should opt for less expensive studies which his skills can enable him to complete quickly. Thus, the financial situation is often a sufficient motivation for the choice of a course.

\section{Other Circumstantial Motivations}

\section{a) Mass Effect}

Le Bon (1998) speaks of an : "orientation by way of suggestion and contagion of feelings and ideas in the same direction, tendency to immediately transform the ideas suggested into action ..." [Our translation]. According to our respondents, there are many baccalaureate holders who do not know which studies to pursue. Every year, more new undecided students arrive at UYI and II. Several of them, when faced with the choice of the course in which to enroll, not knowing what to write, let themselves be influenced by the choices of other students, generally their classmates in high school. The choices made under the influence of the masses are obviously not well thought out and can cause setbacks and dropouts in the academic future of these students. 
b) Higher schools entrance exams failures

Several students enroll in faculty in spite of themselves, never having intended to study in faculties known for their disorder and the difficulties encountered there. They would rather have joined a large school. It is their situation that Fave-Bonnet describes by saying of them that they "often arrive at the University because they could not enter a selective course (preparatory classes for the "grandes écoles », IUT, STS), or that they had to give up private schools of business, management, etc. because they are too expensive. It is therefore often the last choice that students arrive at university ". It is therefore the failure encountered at the entrance of the "grandes écoles » (FMSB, polytechnique, ENAM, Ecole Normale Supérieure, etc.) which motivates the enrollment in faculty of this category of students.

c) Waiting for a better opportunity

A certain number of students, generally from well-off backgrounds, enroll in UYI or II courses while awaiting a possible departure for abroad. They therefore choose the sector that matches what they will have to do outside when possible. Sometimes, they need a good bachelor degree or a good DEUG to be able to continue their studies abroad, and choose the path which can allow them to quickly obtain the required diploma.

In conclusion, Njiale (2002) at the end of his study on the Integration Processes of New Students in Higher Education in Cameroon writes: "for lack of evaluation of the effectiveness of the devices described here, this study, for an objective appreciation of the context, deserves to be supplemented by an investigation of the determinants of choice of orientation and of student success within the various post-baccalaureate training courses. ". It is from this perspective that, in order to understand the fact that so many students make bad choices, it was necessary to examine the motivations and social influences that lie upstream of these choices. March and Simon, cited by Lafaye (1971), showed that: "the rationality of social actors is limited : they, when they make choices, do not look for the optimal solution but stop at the first satisfactory solution. ". This can apply both to new students who choose and to the various social actors who influence their choices. It would therefore be opportune to extend this reflection by examining the different influences in terms of actors and social groups that influence academic orientation.

\section{BIBLIOGRAPHY}

[1] Attias-Donfut, Claudine: 1988, Sociologie des générations, Paris, PUF.

[2] Bourdieu, Pierre and Passeron, Jean-Claude: 1970, La reproduction, Paris, Editions de Minuit.

[3] Bourdieu, Pierre: 1997, Meditations pascaliennes, Paris, Editions du threshold.

[4] Dubet, François: 1997, "Ecole : la question du sens" in Sciences Humaines, n 76, October 1997.

[5] Dumont, Virginie: 1994, Ça ne va pas à l'école, Paris, Pocket.

[6] Durkheim, Emile: 1904, Les règles de la méthode sociologique, Paris, Félix Arcan.

[7] Durkheim, Emile: 1938, L'évolution pédagogique en France, Paris, Quadrige / PUF.

[8] Fournier, Martine: 1995, "Les Héritiers : les étudiants et la culture" in Sciences Humaines, $\mathrm{n}^{\circ}$ 56, December 1995.

[9] Galland, Olivier: 1991, Sociologie de la jeunesse, Paris, Armand Colin.

[10] Georges, François: 1980, "Interview with Gérard MENDEL" in Interviews with the World, n n 6: La société, October 28, 1980.

[11] Lafaye, Claudette: 1971, Sociologie des organisations, Editions Nathan.

[12] Lage, Elisabeth: Lycéens et pratiques scientifiques, Paris, L'Harmattan.

[13] Le Bon, Gustave: 1998, Psychologie des foules, Paris, Quadrige / PUF.

[14] Lourie, Sylvain: 1993, School and Third World, Flammarion, France.

[15] Mendras, Henri: 1989, 1996, Elements de sociologie, Paris, Armand Colin / Masson.

[16] Njiale, Pierre Marie: 2002, Processus d'intégration des nouveaux étudiants dans l'enseignement supérieur au Cameroun: institutionnalisation et finalités de l'orientation universitaire et professionnelle, MINESUP, UYI, Cameroon. 
Sociological Analysis of the Individual Motivations and of Social Origin of the Orientation of the Students of the State Universities of Yaoundé

[17] Pacteau, Chantal: 1994, “Je serai ce que je suis à l'école”, in Human Sciences, number 39, May 1994.

[18] Ruano-Borbalan, Jean-Claude et al: 1998, Eduquer et former, Auxerre, Editions Sciences Humaines.

\section{AUTHOR'S BIOGRAPHY}

Luc Stéphane Massoma, PhD Senior lecturer in the department of Sociology, Anthropology and Social sciences for development of the Faculty of Arts, Letters and Social sciences (University of Maroua, Cameroon). He defended a doctorate at the University of Yaoundé 1 in the Population and Development specialty. His research interests revolve mainly around educational issues, particularly academic and professional orientation. He is also interested in migration issues related to education and development. He is the author of several scientific publications in the above-mentioned fields.

Citation: MASSOMA Luc Stéphane. "Sociological Analysis of the Individual Motivations and of Social Origin of the Orientation of the Students of the State Universities of Yaounde" International Journal of Humanities Social Sciences and Education (IJHSSE), vol 8, no. 4, 2021, pp. 124-131. doi: https://doi.org/10.20431/23490381.0804010.

Copyright: (C) 2021 Authors. This is an open-access article distributed under the terms of the Creative Commons Attribution License, which permits unrestricted use, distribution, and reproduction in any medium, provided the original author and source are credited. 